Article - Agriculture, Agribusiness and Biotechnology

\title{
Biochar and Trichoderma harzianum for the Control of Macrophomina phaseolina
}

\author{
Alyson Silva de Araujo ${ }^{1}$ \\ https://orcid.org/0000-0002-3919-7221 \\ Luiz Eduardo Bassay Blum ${ }^{2}$ \\ https://orcid.org/0000-0002-3968-6615 \\ Cícero Célio de Figueiredo ${ }^{{ }^{*}}$ \\ https://orcid.org/0000-0002-7496-0261 \\ 1University of Brasília, Faculty of Agronomy and Veterinary Medicine, Brasília, DF, Brazil; 2University \\ of Brasília, ${ }^{2}$ Department of Plant Pathology, Brasília, DF, Brazil
}

Received: 2018.05.23; Accepted: 2019.03.30.

* Correspondence: cicerocf@unb.br; Tel.: +55-61-31077564 (C.C.F.)

\section{HIGHLIGHTS}

- Effect of biochar and T. harzianum on the control of M. phaseolina was studied.

- T. harzianum (strain 1306) inhibited the mycelial growth of M. phaseolina.

- Biochar from sewage sludge potentiates the effect of T. harzianum.

- Joint application of biochar $+T$. harzianum increased the mass of bean plants.

Abstract: This study is based on the importance of biological control methods and the lack of information on the effect of biochar $(\mathrm{BCH})$ from sewage sludge associated or not with Trichoderma harzianum on the control of Macrophomina phaseolina in the bean crop (Phaseolus vulgaris, cv. BRS Estilo). Biochar from sewage sludge, pyrolyzed at $500{ }^{\circ} \mathrm{C}$ and used in low concentration $(0.5 \%)$, has a direct effect on the in vitro control of $M$. phaseolina. However, higher $\mathrm{BCH}$ concentrations stimulated the growth of the pathogen. In culture medium with or without $\mathrm{BCH}, T$. harzianum (strain 1306) inhibited the mycelial growth of $M$. phaseolina. The addition of $\mathrm{BCH}+T$. harzianum reduced the deleterious effects caused by M. phaseolina on bean plants. This study demonstrated that joint application of $\mathrm{BCH}$ from sewage sludge $+T$. harzianum considerably increased the fresh and dry mass of bean plants, inoculated or not with M. phaseolina.

Keywords: pyrolysis; biological control; gray rot. 


\section{INTRODUCTION}

Macrophomina phaseolina is an Ascomycota fungus of the family Botryosphaeriaceae [1]. It is an important pathogen inhabiting the soil, distinguished as being polyphagous, cosmopolitan, presenting high pathogenic variability and ability to survive in the soil under adverse conditions. Its growth is favored by high temperatures and low soil moisture, and it is efficiently disseminated by infected seeds [2]. To control this type of pathogen large amounts of chemicals are necessary. In this sense, Brazil is one of the largest consumers of pesticides in the world [3]. Annual sales of agrochemicals in Brazil between the years of 2000 and 2012 grew by $194.1 \%$. In 2014, 508,556.84 tons of active ingredients were sold [4]. However, harm caused to the environment by chemicals have stimulated the study of techniques and the development of alternative methods and biological products for control of plant diseases, considered to be of lesser harm to the environment [5].

Among the alternatives, use of organic residues may influence soil suppression against pathogens by stimulating biota activity, increasing and favoring populations of biocontrol agents, reducing the inoculum potential of phytopathogens, as well as by the action of compounds from the decomposition of organic matter [6]. The use of different types of organic materials applied to soil for control of phytopathogens has been widely evaluated. In this line of research, the possibility for adding biochar $(\mathrm{BCH})$ to the soil has gained attention in different studies; it causes an inhibition or even suppression of the development of phytopathogenic microorganisms, and consequently reduces the severity and incidence of diseases in plants [7-8].

The $\mathrm{BCH}$ is a solid, carbon-rich product obtained by heating biomass under controlled oxygenation conditions, in a process known as pyrolysis [9]. This product can be obtained from various raw materials, such as woody biomass removed from composting, wood waste from commercial forest harvesting operations and urban waste such as sewage sludge. This diversity of raw material used under different conditions results in products with varied properties [10-11]. The raw material and pyrolysis temperature adopted in $\mathrm{BCH}$ production are factors that influence the final characteristics of the product. Biochars produced with different raw materials and at different temperatures present variations in the control of certain diseases, as in the case of damping-off (Rhizoctonia solani) [8]. Another factor also discussed is that higher $\mathrm{BCH}$ concentrations become ineffective or even favor disease, demonstrating a significant interaction between the raw material and $\mathrm{BCH}$ concentration for damping-off control. Thus, BCHs obtained from different raw materials have different optimal concentrations for disease control.

Studies involving the application of $\mathrm{BCH}$ to soil have shown changes in the occurrence of microorganisms and the consequent effects on plant growth. For example, soils that received $\mathrm{BCH}$ showed an increase in the population of Trichoderma spp. in relation to the control soil without BCH [12]. Biological control has been widely studied as an effective alternative for the management of different phytopathogens. The benefits made possible by such control strategies are associated with the fact that it is a safe method that does not pollute and does not cause environmental imbalance, and most importantly promote more sustainable systems that allow subsequent plantations with fewer phytopathological problems [13]. Fungi belonging to the genus Trichoderma are among the most studied and used as biocontrol agents of plant diseases worldwide. Some studies have shown that Trichoderma harzianum has been effective in controlling plant pathogens by its antagonistic action. Trichoderma harzianum was efficient and inhibited the mycelial growth of phytopathogens such as $S$. sclerotiorum and $R$. solani [14-15]. Also, the use of $T$. harzianum isolates in a study of mating with $M$. phaseolina has shown a great phytopathogen inhibition capacity by several mechanisms, such as hyperparasitism and production of volatile compounds by the isolates of this fungus [16].

The objective of the present study was to evaluate the effect of sewage sludge $\mathrm{BCH}$ exclusively or combined with Trichoderma for the control of $M$. phaseolina in bean plants. 


\section{MATERIAL AND METHODS}

The $\mathrm{BCH}$ was produced from sewage sludge biomass (SS) obtained from the sewage treatment plant (STP) of the Federal District Environmental Sanitation Company (CAESB), located at the Gama district, DF, Brazil. This STP utilizes a treatment system at the tertiary level, in which the SS is treated in an upflow anaerobic reactor (UFAR), biological reactor and clarifier. The SS was treated in a drying yard and its characteristics are described in Table 1.

Table 1. Moisture, volatile solids and ash of the sewage sludge.

\begin{tabular}{ccc}
\hline Parameter & Unit & Value \\
\hline Moisture $\left(65^{\circ} \mathrm{C}\right)$ & $\mathrm{g} \mathrm{g}^{-1}$ & 0.17 \\
Volatile solids & $\mathrm{g} \mathrm{g}^{-1}$ & 0.45 \\
Ash & $\mathrm{g} \mathrm{g}^{-1}$ & 0.54 \\
\hline
\end{tabular}

The $\mathrm{BCH}$ was produced in an electric tubular furnace (Linn Elektro Therm) at $500{ }^{\circ} \mathrm{C}$, with temperature elevation rate equal to $11^{\circ} \mathrm{C} \mathrm{min}{ }^{-1}$ and residence time of 30 minutes. The SS samples were placed in a metal vessel adapted to the internal space of the furnace that includes a system for the exit of gases and bio-oil, and a mechanism that avoids oxygen flow. Physico-chemical characterization of the $\mathrm{BCH}$ is described in Table 2.

The bioassay to evaluate the direct effect of $\mathrm{BCH}$ on the growth of $M$. phaseolina was developed in the Department of Phytopathology, located at the University of Brasilia. The culture medium was formulated by adopting $19.5 \mathrm{~g}$ of synthetic PDA (50\% of the quantity specified by the manufacturer) in 1 liter of distilled water, and supplemented with $20 \mathrm{~g}$ of Agar. The $\mathrm{BCH}$ was macerated in a mortar and then passed through a $500 \mu \mathrm{m}$ mesh sieve. Different concentrations of $\mathrm{BCH}$ were tested, with a treatment containing $0 \mathrm{~g}$ of $\mathrm{BCH} / 100 \mathrm{~mL}$ of PDA defined as the control. The concentrations studied were: 0.0, 0.5, 1.0, 2.0, 5.0 and 10.0 ( $\mathrm{g} \mathrm{BCH} / 100 \mathrm{~mL}$ PDA). Culture media were poured onto petri dishes (20 mL / dish). Mycelial discs measuring $5 \mathrm{~mm}$ in diameter were removed from the edges of the $M$. phaseolina colonies. Each treatment consisted of four replicates. The experiment was conducted in a completely randomized design. Mycelial growth of the phytopathogen under different $\mathrm{BCH}$ concentrations was counted on the seventh day after assembly of the experiment.

Table 2. Physico-chemical properties of the biochar produced under different pyrolysis temperatures.

\begin{tabular}{ccc}
\hline Properties & Sewage sludge & BCH 500 \\
\hline SSA $\left(\mathrm{m}^{2} \mathrm{~g}^{-1}\right)$ & - & 52.470 \\
$\mathrm{PV}\left(\mathrm{ml} \mathrm{g}^{-1}\right)$ & - & 0.053 \\
$\mathrm{pH}$ & 4.8 & 6.5 \\
$\mathrm{EC}\left(\mathrm{mS} \mathrm{cm}^{-1}\right)$ & 3.3 & 2.3 \\
$\mathrm{C}(\%)$ & 21.0 & 19.0 \\
$\mathrm{~N}(\%)$ & 3.0 & 2.3 \\
$\mathrm{H}(\%)$ & & 1.7 \\
$\mathrm{C} / \mathrm{N}$ & - & 8.1 \\
$\mathrm{H} / \mathrm{C}$ & 2.4 & 1.07 \\
Nitrate $\left(\mathrm{mg} \mathrm{kg}^{-1}\right)$ & - & 5.838 \\
Ammonium $\left(\mathrm{mg} \mathrm{kg}^{-1}\right)$ & - & 169.288 \\
\hline
\end{tabular}

SSA: specific surface area; PV: pore volume; EC: electrical conductivity; C: total carbon; N: total nitrogen; $\mathrm{H}$ : hydrogen; $\mathrm{BCH} 500$ : biochar pyrolyzed at $500^{\circ} \mathrm{C}$. 
A second experiment reassessed the direct effect of a certain $\mathrm{BCH}$ concentration on the mycelial growth of $M$. phaseolina and the effectiveness of $T$. harzianum as a biocontrol agent of the phytopathogen in culture medium with and without $\mathrm{BCH}$. The culture medium was produced according to the methodology established in the first experiment.

The fungus $T$. harzianum (Tricodermi|®) strain 1306 was grown on PDA culture medium and streaked on plates where the pairs were made. Mycelial discs measuring $5 \mathrm{~mm}$ in diameter were removed from the borders of the $T$. harzianum and $M$. phaseolina colonies, both after three days of growth on PDA. The treatments of this experiment were: $M$. phaseolina on PDA (control), T. harzianum on PDA (control), M. phaseolina on PDA $+\mathrm{BCH}$, $T$. harzianum on PDA $+\mathrm{BCH}, M$. phaseolina $\times T$. harzianum on PDA, M. phaseolina $\times T$. harzianum on PDA $+\mathrm{BCH}$. Mycelial growth of $M$. phaseolina was quantified on the seventh day after assembly of the experiment. This experiment consisted of six repetitions, in a completely randomized design.

A third experiment was conducted seeking to evaluate the control of $M$. phaseolina in function of the use of $\mathrm{BCH}$ and the association $\mathrm{BCH}+T$. harzianum when applied to the soil, as well as the agronomic gains associated with these treatments in the bean culture cultivated in pots under greenhouse conditions. The $\mathrm{BCH}$ produced at $500{ }^{\circ} \mathrm{C}$ was sieved with a $8 \mathrm{~mm}$ mesh. For the test, bean seeds ( $P$. vulgaris) of the cultivar BRS Estilo were used. Sowing of the plant species was performed in $4 \mathrm{~L}$ pots with previously autoclaved soil, using 5 seeds per pot.

The first inoculation with $M$. phaseolina occurred five days prior to bean sowing, by means of soil infestation using 50 microsclerotia / $\mathrm{g}$ of soil. The second inoculation occurred via immersion of seeds in a suspension of microsclerotia (73 microsclerotia / $\mathrm{mL}$ ), with exposure of the seeds to the pathogen for 60 minutes. The treatments used were: 1) plant (control), 2) plant $(\mathrm{PI})+\mathrm{M}$. Phaseolina, 3) $\mathrm{PI}+\mathrm{BCH}$, 4) $\mathrm{PI}+\mathrm{BCH}+$ M. Phaseolina, 5) $\mathrm{PI}+T$. Harzianum, 6) $\mathrm{PI}+T$. harzianum $+M$. Phaseolina, 7) $\mathrm{PI}+T$. harzianum $+\mathrm{BCH}$, 8) $\mathrm{PI}+T$. harzianum $+\mathrm{BCH}+$ M. phaseolina.

Trichoderma harzianum was applied to the soil at two times, eight days prior to sowing and at the time of planting, applying $40 \mathrm{~mL}$ per pot of the conidia suspension ( $1 \times 10^{6}$ conidia $\mathrm{mL}^{-1}$ ), using sterilized distilled water for determination of this activity.

The experiment was conducted in a randomized complete block design with 4 replicates. Evaluations started on the eighth day after sowing, adopting a system of observations every 48 hours. The following plant evaluations were performed: percentage of germinated seeds (NSG) 13 days after sowing; number of pods at the end of the experiment; and the fresh and dry mass per pot considering the shoots and roots.

Analyses were performed using the IBM SPSS Statistics program, version 23.0 [17]. The data were analyzed by analysis of variance, and the treatments were compared by Tukey's test $(p<0.05)$.

\section{RESULTS AND DISCUSSION}

Enrichment of the PDA culture medium with sewage sludge $\mathrm{BCH}$ revealed a direct effect on growth of the $M$. phaseolina fungus (Fig. $1 \mathrm{~A}$ ). BCH, at concentrations of 0.5 and $1.0 \%$, reduced phytopathogen growth. These concentrations promoted an inhibition of fungal mycelial growth, reducing its growth rate in the culture medium when compared to the control. Low concentrations of $\mathrm{BCH}(0.5$ and $1.0 \%)$ in the culture medium promoted an inhibition of this phytopathogen. However, high concentrations of $\mathrm{BCH}$ increased the fungus growth rate and stimulated its development in vitro. 

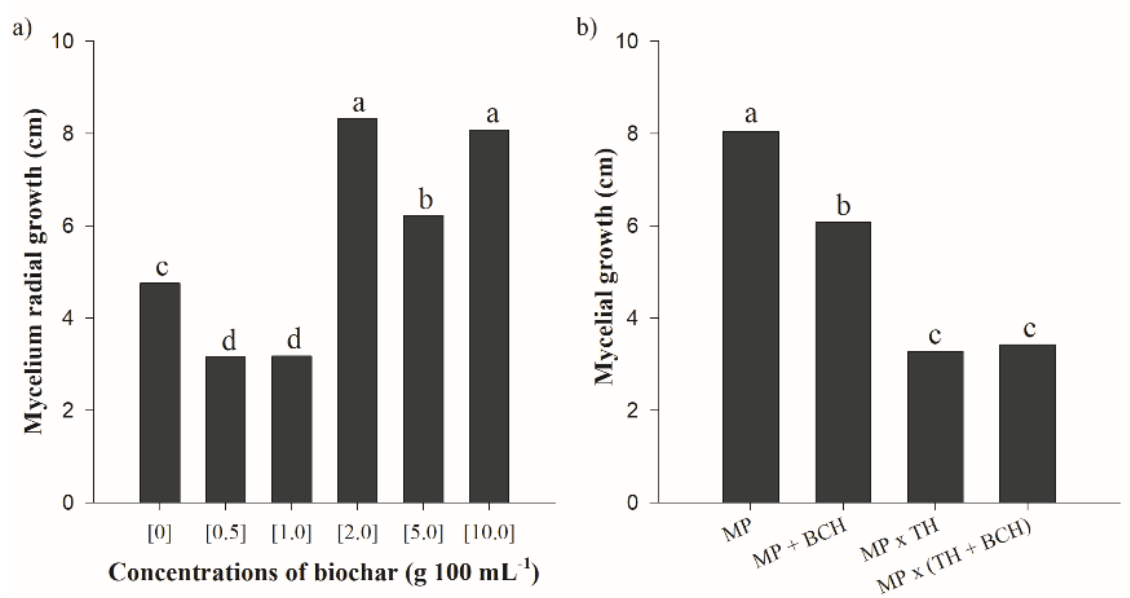

Figure 1. Evaluation of mycelial growth of the fungus $M$. phaseolina. (a) Mycelial growth $(\mathrm{cm})$ of $M$. phaseolina in different concentrations of biochar $\left(500^{\circ} \mathrm{C}\right)$. (b) Pairing of the species [M. phaseolina $\mathrm{x}$ T. harzianum] in culture medium without and with biochar $[0.5 \%]$. ([0] $=$ control, $[0.5]=$ culture medium with $0.5 \%$ of biochar $500 \stackrel{\circ}{\circ},[1.0]=$ culture medium with $1.0 \%$ biochar $500 \stackrel{\circ}{\circ}$, [2.0] = culture medium

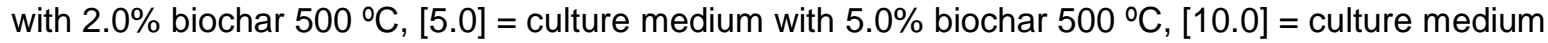
with $10.0 \%$ biochar $500{ }^{\circ} \mathrm{C}$, MP - M. phaseolina, $\mathrm{BCH}$ - biochar $500{ }^{\circ} \mathrm{C}, \mathrm{TH}-\mathrm{T}$. harzianum). Means followed by the same letters do not present significant differences [Tukey test $(p<0.05)$ ].

Increased salinity in the PDA culture medium, resulting from the addition of $\mathrm{NaCl}+$ $\mathrm{CaSO}_{4}$ or $\mathrm{CaSO}_{4}$, stimulated the development and infection of two $M$. phaseolina isolates [18]. Biochars produced at $500{ }^{\circ} \mathrm{C}$ presented higher values of electrical conductivity (EC) than those produced at lower temperatures [19]. The possible increase in EC of the PDA culture medium after addition of sewage sludge $\mathrm{BCH}$ may be related to the stimulus of mycelial growth of the $M$. phaseolina fungus observed in the experiment. Moreover, with low $\mathrm{C} / \mathrm{N}$ ratio (Table 2), $\mathrm{BCH}$ may have served as a substrate for the development of $M$. phaseolina when doses higher than $1 \%$ were applied. Although predominantly composed of recalcitrant carbon, $\mathrm{BCH}$ also exhibits readily decomposable compounds [19] which can be used for microbial growth.

However, the action of $\mathrm{BCH}$ seems to be specific for a given pathosystem. In vitro assays using $\mathrm{BCH}$ produced from eucalyptus wood $\left(600^{\circ} \mathrm{C}\right)$ and pepper residues $\left(350^{\circ} \mathrm{C}\right)$, when added at different concentrations $(0,0.5,1$, and $3 \%)$ to the culture medium, did not inhibit mycelial growth of the phytopathogen Fusarium oxysporum f. sp. radicis lycopersici compared to the unmodified control (without biochar), indicating that for the tested pathosystem the direct effect of biochar cannot be considered a mechanism of disease suppression [20].

Pairing of the fungi $M$. phaseolina $\times T$. harzianum (strain 1306) demonstrated the effectiveness of biological control on phytopathogen growth (Fig. 1 B). The existing biological control mechanism of Trichoderma on the fungus $M$. phaseolina can be based on three antagonistic activities: competition, antibiosis and via hyperparasitism [21]. The results of the present work, obtained in PDA culture media, enriched or not with biochar, showed similar results to the work of Mendonza et al. [21] who observed a barrier at the contact site of the microorganisms, interrupting development of the phytopathogen. Subsequently, $T$. harzianum was found by colonizing the hyphae of $M$. phaseolina, as well as the rest of the Petri dish. The obtained results confirmed the capacity of the sewage sludge $\mathrm{BCH}$ to inhibit mycelial growth of the phytopathogen.

Eleven isolates of Trichoderma (five isolates of $T$. harzianum and six of $T$. viride) promoted inhibition of $M$. phaseolina in assays in vitro, demonstrating the promising biological control ability exerted by this fungus genus [22]. These authors observed that two 
T. harzianum isolates were distinguished from the other microorganisms by promoting greater control of the M. phaseolina fungus, with inhibition indices of 57.3 and $58.7 \%$.

The results obtained in the present work, when associated to the scale of Bell et al. [23], demonstrate that the antagonist grows throughout the Petri dish, thus confirming the efficiency of $T$. harzianum (strain 1306) for control of $M$. phaseolina in the presence or absence of $\mathrm{BCH}$ from sewage sludge.

Inoculation with the fungus $M$. phaseolina caused damage to the bean crop, cultivar BRS Estilo. The results showed a significant reduction in the germination percentage, reflecting a lower number of emerged seedlings compared to results obtained in the absence of the phytopathogen (Fig. 2 A). The different treatments had no effect on the percentage of emerged bean seedlings when in the absence of the phytopathogen $(p<0.05)$. The use of $\mathrm{BCH}$ from sewage sludge combined with $T$. harzianum proved to be effective for the control of $M$. phaseolina, providing a significant increase in the germination percentage compared to the inoculated control.

The treatment of bean seeds with different species of Trichoderma affected the percentage and speed of crop germination [24]. Use of $T$. harzianum provided an emergence index of $94.16 \%$ for bean seedlings, a result greater than $66.66 \%$ as recorded in the control (seeds not inoculated with the microorganism).
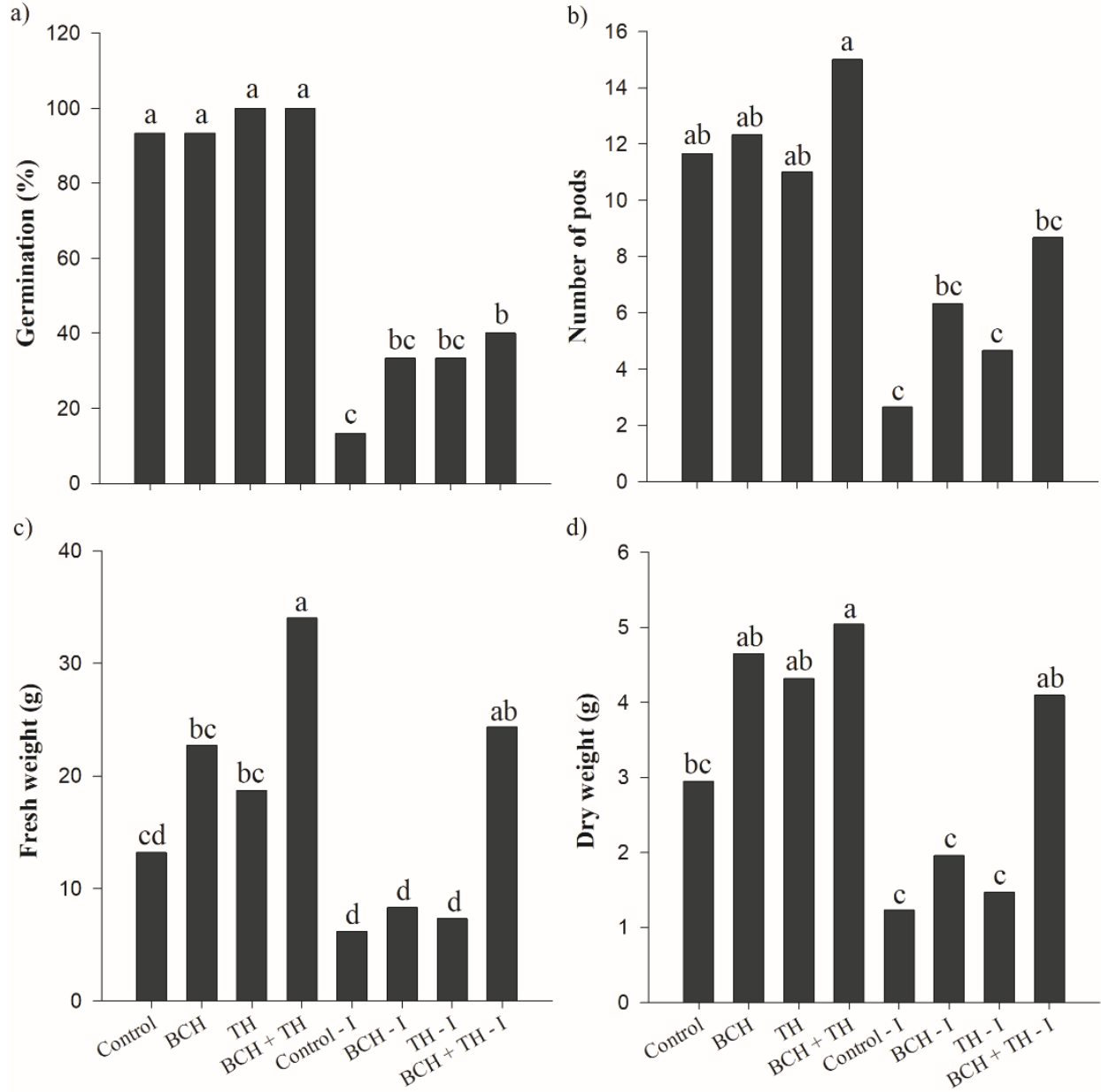

Figure 2. Bean plants (P. vulgaris) submitted to different treatments, inoculated or not with $M$. phaseolina. (a) Percentage of germinated seeds. (b) Number of pods per pot. (c) Fresh mass (g) per pot. (d) Dry mass (g) per pot. Equal letters indicate that there is no significant difference [Tukey's test $(p<0.05)]$

In the present work, joint application of the sewage sludge biochar with $T$. harzianum did not increase the number of pods per pot of the bean plants, in the absence or presence of the $M$. phaseolina fungus (Fig. $2 \mathrm{~B}$ ). However, the use of $\mathrm{BCH}$ provided results similar to those achieved by non-inoculated plants (with the exception of the $\mathrm{BCH}+T$. harzianum 
association). In a different pot experiment, the application of $T$. harzianum to the soil increased the number of pods and nodules in roots of bean plants (Vicia faba L.) inoculated with $M$. phaseolina [25]. These authors emphasized that this biological control agent promoted a $6 \%$ increase in shoot length and $24 \%$ increase in root length.

The incorporation of different biochar types to the soil, produced from rice husks (430 $\left.{ }^{\circ} \mathrm{C}\right)$, sawdust $\left(385^{\circ} \mathrm{C}\right.$ ) or sorghum silage $\left(385^{\circ} \mathrm{C}\right)$, improved the chemical properties of the soil and also reflected a yield increase (higher dry mass) and accumulation of nutrients in the bean plant grains [26].

The fresh and dry masses evaluated in the present work demonstrated the benefits obtained from the application of $\mathrm{BCH}$ to the soil, as well as the importance that beneficial microorganisms like $T$. harzianum have on bean development. Application of these treatments together promoted an increase in fresh mass of approximately three times that obtained by control in the absence of the pathogen (Fig. $2 \mathrm{C}$ ).

Similar to our results, $\mathrm{BCH}$ from sewage sludge applied to the soil stimulated both growth and production of bean biomass, guaranteeing a $21 \%$ increase in shoot biomass and $27 \%$ increase in bean yield [27]. The authors cited that this increase can be attributed to improved soil fertility from the addition of sewage sludge $\mathrm{BCH}$. Moreover, the ability of biochar to protect Trichoderma favored its survival in the soil and the direct role of microorganisms on plant growth are indicated as possible explanations for the beneficial effects obtained. Furthermore, there is also the possibility that Trichoderma makes nutrients present in the biochar available to the soil [28].

Biochar has been highlighted due to its possible influence on the complex rhizospheric system, interacting with root/soil/pathogen by virtue of a series of physical and chemical properties, such as: nutrient content, water retention capacity, redox activity, adsorption capacity, $\mathrm{pH}$ and content of toxic and hormonal compounds [29]. The authors also emphasized that these properties of biochar can affect the guidelines of the disease triangle (environment, host and pathogen) directly and/or indirectly (through the rhizosphere microbiota), and consequently influence the development of plants, as well as the progress of the disease.

The dry mass results (Fig. 2 D) show the same behavior as those of fresh mass, confirming that the application of biochar together with $T$. harzianum has the greatest effect on mass increase when this treatment is compared with the control, with or without inoculation of $M$. phaseolina $(\mathrm{p}<0.05)$.

The use of $\mathrm{BCH}$ from sewage sludge in a pot experiment increased the soil nutrient content, with the exception of potassium $(\mathrm{K})$, increasing values of soil fertility indicators represented by the sum of bases, effective cation exchange capacity, cation exchange capacity and base saturation when considering increased radish development [30]. Compared to other organic residues the sewage sludge $\mathrm{BCH}$ has high levels of $\mathrm{N}$, mainly as $\mathrm{N}-\mathrm{NH}_{4}{ }^{+}$(Table 2), which reinforces its nutritional role in increasing the dry mass of bean plants.

Similarly, the application of biochar from eucalyptus wood $\left(600^{\circ} \mathrm{C}\right)$ to the soil resulted in a decrease of up to $61 \%$ in fusarium wilt in tomato plants, just as plants cultivated in soil without biochar showed wilt symptoms one day before those containing biochar [20]. The authors emphasized that application of biochar to the soil stimulated rhizospheric microbial diversity related to the genera known for promoting plant growth, suppressing diseases, possible ecological roles (decomposition of organic compounds) and biological nitrogen fixation.

Inoculation with $M$. phaseolina caused damage to the bean crop, reflecting low production of fresh and dry mass by the plants. However, the $\mathrm{BCH}+T$. harzianum association for control of the disease evaluated in this study showed high effectiveness in phytopathogen inhibition compared with the other treatments, resulting in a greater difference in mass $(\mathrm{g})$ in relation to the inoculated control. Similarly, Trichoderma viride applied to the soil altered the biodynamics of rye plants (Secale cereale L.), increasing the number of leaves in relation to the control [31]. The authors observed that use of wood 
biochar resulted in better survival of Trichoderma spp. during the 35 experimental days, and consequently, better development of the plants.

Treatment of seeds with a specific $T$. harzianum isolate caused an increase in growth of the bean plants, resulting in a larger leaf area, root area and a greater number of secondary roots [32]. Changes in structure of the microbial communities and microfauna of the soil resulting from the application of organic materials are described as potentially responsible for the suppression of phytopathogenic fungi and reduced incidence of disease in ginseng (Panax ginseng) [33]. The authors described an increase in fungivorous nematodes, as well as an increased amount and bacterial activity in the soil after addition of organic material, defining bacteria as a candidate group to suppress fungal pathogens of root rot.

\section{CONCLUSION}

The present study demonstrated that biochar from sewage sludge, pyrolyzed at $500{ }^{\circ} \mathrm{C}$ and used at low concentrations ( 0.5 and $1.0 \%)$, has a direct effect on in vitro control of the $M$. phaseolina fungus. This in vitro study also demonstrated the efficiency of biological control of the phytopathogen exerted by Trichoderma harzianum (strain 1306) in culture medium with or without biochar. The fungus $M$. phaseolina caused damage to the bean crop, reflected in a reduction of all the agronomic indices evaluated in this study (germination, number of pods, fresh and dry mass) in common bean plants. When applied together the $\mathrm{BCH}$ from sewage sludge potentiates the effect of $T$. harzianum. As a result, this combination increased the percentage of germinated seeds, and the fresh and dry biomass of bean plants inoculated with the phytopathogen.

Funding: This research was funded by the SUPPORT RESEARCH FOUNDATION OF THE FEDERAL DISTRICT, grant number 0193.002020/2017.

Acknowledgments: Luiz Eduardo Bassay Blum and Cícero Célio de Figueiredo would like to thank The National Council of Technological and Scientific Development (CNPq) for the research productivity fellowship.

Conflicts of Interest: The authors declare no conflict of interest. The funders had no role in the design of the study; in the collection, analyses, or interpretation of data; in the writing of the manuscript, or in the decision to publish the results.

\section{REFERENCES}

1. Mycobank. Macrophomina phaseolina. Available online: http://www.mycobank.org/Biolomics.-aspx?Table=Mycobank (accessed on 21 November 2016).

2. Gomes, D.P.; Silva, G.C.; Kronka, A.Z.; Torres, S.B.; Souza, J.R. de. Qualidade fisiológica e incidência de fungos em sementes de feijão-caupi produzidas do Estado do Ceará. Rev. Caatinga 2008, 21 (2), pp. 165-171.

3. MMA. Ministério do Meio Ambiente. Segurança química - Agrotóxicos. Available online: http://www.mma.gov.br/seguranca-quimica/agrotoxicos (accessed on 13 December 2016).

4. IBAMA. Instituto Brasileiro do Meio Ambiente. Boletim Anual de Produção, Importação, Exportação e Vendas de Agrotóxicos no Brasil: Histórico de Comercialização 2000 - 2014. Available online:

http://www.ibama.gov.br/phocadownload/qualidadeambiental/relatorios/2014/grafico_histori-co_com ercializacao_2000_2014.pdf (accessed on 4 November 2016).

5. Broetto, L.; Coltro-Roncato, S.; Meinerz, C.C.; Dildey, O.D.F.; Pazdiora, P.C.; Gonçalves, E.D.V.; et al. Crescimento micelial e produção de microescleródios de Macrophomina phaseolina confrontado com diferentes isolados de Trichoderma sp. Sci. Agrar. Paran. 2014, 13 (4), pp. 310-317. 6. Bettiol, W.; Ghini, R.; Mariano, R.R.L.; Michereff, S.J.; Mattos, L.P.V.; Alvarado, I.C.; et al. Supressividade a fitopatógenos habitantes do solo. In Biocontrole de doenças de plantas: uso e perspectivas; Bettiol, W., Morandi, M.A.B.; Publisher: Jaguariúna: Embrapa Meio-Ambiente, Brasil, 2009; Volume 1, pp. 187-208. 
7. Elmer, W.H.; Pignatello, J.J. Effect of biochar amendments on mycorrhizal associations and Fusarium crown and root rot of asparagus in replant soils. Plant Dis. 2011, 95, pp. 960-966.

8. Jaiswal, A.K.; Elad, Y.; Graber, E.R.; Frenkel, O. Rhizoctonia solani suppression and plant growth promotion in cucumber as affected by biochar pyrolysis temperature, feedstock and concentration. Soil Biol. Biochem. 2014, 69, pp. 110-118.

9. Sohi, S.P. Carbon storage with benefits. Science 2012, 338, pp. 1034-1035.

10. Hartley, W.; Riby, P.; Waterson, J. Effects of three different biochars on aggregate stability, organic carbon mobility and micronutrient bioavailability. J. Environ. Manage. 2016, 181, pp. 1-9.

11. Yuan, H.; Lu, T.; Huang, H.; Zhao, D.; Kobayashi, N.; Chen, Y. Influence of pyrolysis temperature on physical and chemical properties of biochar made from sewage sludge. J Anal Appl Pyrolysis 2015, 112, pp. 284-289.

12. Graber, E.R.; Harel, Y.M.; Kolton, M.; Cytryn, E.; Silber, A.; David, D.R.; et al. Biochar impact on development and productivity of pepper and tomato grown in fertigated soilless media. Plant Soil 2010, 337, pp. 481-496.

13. Scudeler, F.; Venegas, F. Trichoderma harzianum associado ou não a fungicidas em tratamento de sementes na cultura do milho (Zea mays L.). Ensaios e Ciência: C Biológicas, Agrárias e da Saúde 2012, 16 (5), pp. 9-19.

14. Góes, L.B.; Costa, A.B.L. da; Freire, L.L.C.; Oliveira, N.T. de. Randomly amplified polymorphic DNA of Trichoderma isolates and antagonism against Rhizoctonia solani. Braz. Arch. Biol. Technol. 2002, 45 (2), pp. 151-160.

15. Figueirêdo, G.S. de; Figueirêdo, L.C. de; Cavalcanti, F.C.N.; Santos, A.C. dos; Costa, A.F. da; Oliveira, N.T. de. Biological and chemical control of Sclerotinia sclerotiorum using Trichoderma spp. and Ulocladium atrum and pathogenicity to bean plants. Braz. Arch. Biol. Technol. 2010, 53 (1), pp. 1-9.

16. Khalili, E.; Javed, M.A.; Huyop, F.; Rayatpanah, S.; Jamshidi, S. Wahab, R.A. Evaluation of Trichoderma isolates as potential biological control agent against soybean charcoal rot disease caused by Macrophomina phaseolina. Biotechnol. Biotechnol. Equip. 2016, 30 (3), pp. 479-488.

17. IBM Corp. Released 2015. IBM SPSS Statistics for Windows, Version 23.0. Armonk, NY: IBM Corp. 2015.

18. You, M.P.; Colmer, T.D.; Barbetti, M.J. Salinity drives host reaction in Phaseolus vulgaris (Common bean) to Macrophomina phaseolina. Funct. Plant. Biol. 2011, 38, pp. 984-992.

19. Figueiredo, C.; Lopes, H.; Coser, T.; Vale, A.; Busato, J.; Aguiar, N.; et al. Influence of pyrolysis temperature on chemical and physical properties of biochar from sewage sludge. Arch. Agron. Soil Sci. 2018, 64 (6), pp. 881-889.

20. Jaiswal, A.K.; Elad, Y.; Paude, I.; Graber, E.R.; Cytryn, E.; Frenkel, O. Linking the belowground microbial composition, diversity and activity to soilborne disease suppression and growth promotion of tomato amended with biochar. Sci. Rep. 2017, 7 (44382), pp. 1-17.

21. Mendoza, J.L.; Pérez, M.I.; Prieto, J.M.; Velásquez, J.D.; Olivares, J.G.; Langarica, H.R. Antibiosis of Trichoderma spp strains native to northeastern Mexico against the pathogenic fungus Macrophomina phaseolina. Braz. J. Microbiol. 2015, 46 (4), pp. 1093-1101.

22. Khaledi, N.; Taheri, P. Biocontrol mechanisms of Trichoderma harzianum against soybean charcoal rot caused by Macrophomina phaseolina. J. Plant Prot. Res. 2016, 56 (1), pp. 21-31.

23. Bell, D.K.; Wells, H.D.; Markhan, C.R. In vitro antagonism of Trichoderma species against six fungal plant pathogens. Phytopathology 1982, 72 (4), pp. 379-382.

24. Pierre, E.; Louise, N.W.; Marie, T.K.R.; Valère, T.F.P.; Arc-En-Ce, J.M.; Fekam, B.F. Integrated assessment of phytostimulation and biocontrol potential of endophytic Trichoderma spp against common bean (Phaseolus vulgaris L.) root rot Fungi Complex in Centre Region, Cameroon. Int. J. Pure App. Biosci. 2016, 4 (4), pp. 50-68.

25. Kumari, R.; Khan, M.R.; Bagri, G.K.; Bagri, D.K.; Bagdi, D.L. Soil application of different species of Trichoderma for the management of charcoal rot of faba bean caused by Macrophomina phaseolina. J. Pharmacogn. Phytochem. 2017, 6 (6), pp. 1483-1486.

26. Silva, I.C.B. da; Basílio, J.J.N.; Fernandes, L.A.; Colen, F.; Sampaio, R.A.; Frazão, L.A. Biochar from different residues on soil properties and common bean production. Sci. Agric. 2017, 74 (5), pp. 378-382. 
27. Ibrahim, M.; Li, G.; Khan, S.; Chi, Q.; Xu, Y. Biochars mitigate greenhouse gas emissions and bioaccumulation of potentially toxic elements and arsenic speciation in Phaseolus vulgaris L. Environ. Sci. Pollut. Res. 2017, 24 (24), pp. 19524-19534.

28. Muter, O.; Grantina-levina, L.; Makarenkova, G.; Vecstaudza, D.; Strikauska, S.; Selga, T.; Kasparinskis, R.; Stelmahere, S.; Steiner, C. Effect of biochar and Trichoderma application on fungal diversity and growth of Zea mays in a sandy loam soil. Environ. Exper. Biol. 2017, 15, pp. 289-296. 29. Graber, E.R.; Frenkel, O.; Jaiswal, A.K.; Elad, Y. How may biochar influence severity of diseases caused by soilborne pathogens? Carbon Manag. 2014, 5 (2), pp. 169-183.

30. Sousa, A.A.T.C.; Figueiredo, C.C. Sewage sludge biochar: effects on soil fertility and growth of radish. Biol. Agric. Hortic. 2016, 32 (2), pp. 127-138.

31. Vecstaudza, D.; Grantina-levina, L.; Makarenkova, G.; Kasparinskis, R.; Selga, T.; Steinberga, V.; Stelmahere, S.; Steiner, C.; Muter, O. The impact of wood-derived biochar on the survival of Trichoderma spp. and growth of Secale cereale L. in sandy soil. Biocontrol Sci. Technol. 2018, 28 (4), pp. 341-358.

32. Pereira, J.L.; Queiroz, R.M.L.; Charneau, S.O.; Felix, C.R.; Ricart, C.A.O.; Silva, F.L. da; et al. Analysis of Phaseolus vulgaris response to its association with Trichoderma harzianum (ALL-42) in the presence or absence of the phytopathogenic Fungi Rhizoctonia solani and Fusarium solani. PLoS ONE 2014, 9 (5) (e98234), pp. 1-23.

33. Eo, J.; Park, K.C.; Kim, M.H.; Kwon, S.I.; Song, Y.J. Effects of rice husk and rice husk biochar on root rot disease of ginseng (Panax ginseng) and on soil organisms. Biol. Agric. Hortic. 2017, 34 (1), pp. 27-39.

(C) 2018 by the authors. Submitted for possible open access publication under the terms and conditions of the Creative Commons Attribution (CC BY NC) license (http://creativecommons.org/licenses/by-nc/4.0/). 